\title{
ТЕОРЕТИКО-МЕТОДОЛОГІЧНІ ОСНОВИ ВИЗНАЧЕННЯ ЕМОЩЙНИХ СТАНІВ У СУЧАСНІЙ ПСИХОЛОГІї
}

\author{
Михайлишин У. Б.
}

\section{ВСТУП}

Значення проблеми емоцій навряд чи потребує обгрунтування. Які б умови та детермінанти не визначали життя і діяльність людини внутрішньо, проте психологічно дієвими вони стають лише в тому разі, якщо їм удається проникнути у сферу iї емоційних відносин, асимілюватися і закріпитися в ній. Така універсальна значущість емоцій повинна бути, здавалося б, надійною запорукою як підвищеного інтересу до них, так і порівняно високого ступеня їх вивченості. I дійсно, протягом багатовікової історії емоційна сфера людини перебувала під найбільш пильною увагою, емоціям відводилася одна 3 центральних ролей серед сил, що визначають внутрішне життя і вчинки людини.

У психологічній науці проблемі емоційної сфери особистості присвячено багато теоретичних та емпіричних робіт таких зарубіжних і вітчизняних дослідників, як В. Вундт, М. Грот, 3. Фрейд, У. Джеймс, Г. Ланге, С.Л. Рубінштейн, І. Ізард, О.М. Леонтьєв, С.П. Ільїн та багато інших. На сучасному етапі увага приділяється вивченню емоційної сфери в контексті навчальної діяльності (М.А. Кузнєцов, О.П. Саннікова, О.Я. Чебикін), професійної діяльності (О.М. Бандурка, С.П. Бочарова, О.В. Землянська, О.В. Тімченко). Розглядається роль емоцій у формуванні правової поведінки особистості (І.О. Віденєєв, I.В. Жданова, О.В. Землянська, М.І. Єнікєєв, В.С. Коновалова, М.В. Костицький, О.Л. Ситковська).

Огляд теоретичних напрямів у розвитку уявлень про емоції показав, що немає єдиної теорії, яка б відповідала на всі питання психології емоцій. Тому ці теорії слід розглядати як взаємодоповнювальні, враховувати всі відкриті ними факти в теоретичній і практичній діяльності. Таким чином, складність структури та змісту емоційної сфери особистості зумовила різноманітність підходів до проблеми виникнення емоційних процесів і станів.

\section{1. Стан дослідження проблеми емоційної сфери, основні теорії емоцій та почуттів особистості}

Інтелектуалістичний підхід емоційного реагування (XVIII-XIX ст.) передбачав дослідження інтелектуальної основи емоцій: вони 3'являються в момент розбіжності уявлень людини про одні й ті ж 
об'єкти (явища, ситуації тощо). Наприклад, контраст між уявленням людини про те, що має відбутися у важливій для нього ситуації, і тим, що відбулося насправді, породжує або почуття задоволення, або гніву. Тобто представники цієї школи зараховували емоції до особистісних проявів.

Еволюційна теорія емоційного реагування (Ч. Дарвін) засвідчувала, що емоції - результат еволюції живих істот у процесі їх виживання та адаптації до умов існування. Страх, наприклад, надавав їм додаткову енергію (для порятунку втечею від джерела небезпеки). Емоції викликали і тілесні зміни, що відповідали змінам у навколишньому середовищі. Поряд із загальною підготовкою організму до дії окремі емоційні стани супроводжуються змінами в пантоміміці, міміці звуковими реакціями. Яке б не було початкове походження і призначення цих реакцій ${ }^{1}$, та в еволюції вони розвивалися і закріплювалися як засоби оповіщення про емоційний стан індивіда у внутрішньовидовому і міжвидовому спілкуванні. Із підвищенням ролі спілкування у вищих тварин виразні рухи стають тонкою диференційованою мовою, за допомогою якої індивіди обмінюються інформацією як про свій стан, так і про те, що відбувається в середовищі (сигнали небезпеки, їжі тощо). Експресивна функція емоції не втратила свого значення i після того, як в історичному розвитку людини сформувалася більш досконала форма обміну інформацією членороздільна мова. Емоційна експресія вдосконалилася завдяки тому, що грубі вроджені форми вираження стали доповнюватися більш тонкими нормами, що засвоюються в онтогенезі. Експресія як функція емоцій - здатність емоцій виступати тонким диференційованим засобом 3 обміну інформацією у внутрішньо- і міжвидовому спілкуванні через пантоміміку, міміку, звукові реакції.

Водночас прихильники «еволюції навпаки» вважають за можливе походження тварин від первісної людини в результаті безсистемної асиміляції з рештою світу. І цим пояснюють емоції тваринного світу.

Інші ж, які наголошують на релігійній основі, впевнені, що живий світ був одночасно створений «вищим розумом» разом зі специфічною для кожного представника емоційною сферою. Таким чином, у філогенезі емоційної сфери особистості між людьми «згоди немає» й досі.

Фізіологічна теорія емоційного реагування І.П. Павлова визнає як основний механізм емоцій кору головного мозку i підкіркові утворення ${ }^{2}$. Емоції розглядаються як генетично зумовлені процеси, які визначаються лімбічною системою (найбільш древньою структурою мозку) та пов'язаною 3 нею ретикулярною формацією і вегетативною

1 Дарвин Ч. Сочинения. Том 5. Происхождение человека и половой отбор. Выражение эмоций у человека и животных. Москва, 1953. 215 с.

${ }^{2}$ Павлов И. П. Полное собрание сочинений. 2-е изд. / за ред. Э. Ш. Айрапетьянц. Ленинград, 1951. Т. 1.324 с. 
нервовою системою. Перезбудження кори i підкіркових центрів призводить до імпульсивної неконтрольованої поведінки людини, надмірне гальмування - до депресивної поведінки. Провідна роль у формуванні емоцій визнана за правою півкулею кори головного мозку. У гіпоталамусі виявлені центри агресії, страждання, задоволення, насолоди («пекло і рай розміщуються поруч»).

Органічні зміни (біоструми мозку, електропровідність шкіри, час реакції тощо) як наслідок емоційних станів можуть бути об'єктивно виміряні апаратурними засобами у вигляді електроенцефалограми, шкірно-гальванічної реакції тощо. Ідея фіксації контрасту емоційних станів, що спричинені надходженням різної за значущістю для людини інформації, використовується в поліграфі («детектор брехні»).

Психоорганічна (таламічна) теорія У. Кеннона і П. Барда не допускає проявів фізіологічних змін в організмі раніше, ніж з'являться емоції․․ На думку авторів, емоції або випереджають фізіологічні зміни в організмі, або виникають разом із ними. Роботу механізму проявів емоцій вони пов'язують із впливом подразників на таламус. Саме звідси надходять імпульси збудження в кору головного мозку.

Біхевіористська теорія емоційного реагування Дж. Уотсона розглядає емоції як реакції на специфічні стимули (так, любов породжується ласками і увагою, страх - втратою підтримки тощо). У центрі теорії лежить поняття «типова емоційна поведінка»: кожному «зразку» поведінки відповідає свій стимул. I зумовлено це лише досвідом людини. «Батько» біхевіоризму Дж. Уотсон був упевнений, що до безумовних реакцій можна зарахувати тільки гнів, страх і любов. Інші реакції є умовними, вони формуються в людини в результаті навчання ${ }^{4}$.

3. Фрейд і психоаналітична теорія афекту посідають особливе місце в історії психології та науках про поведінку з багатьох причин. 3. Фрейд створив евристичні концепції несвідомого, динаміки сновидінь, розвитку свідомості захисних механізмів. Аналіз функціонування особистості допоміг піддати дослідженню сферу людської мотивації, зробив іiї значною частиною сучасної психології $\mathrm{i}$ дав початок психодинамічній традиції. Найбільший інтерес для нас становить фрейдівська концепція афектів.

Уявити цілісне визначення афекту в термінах класичної психоаналітичної теорії нелегко, оскільки 3. Фрейд та його послідовники використовували це поняття досить широко і приписували йому різні ролі в процесі розвитку теорії. У своїх ранніх роботах 3. Фрейд стверджував, що афект (емоція) $є$ лише

${ }^{3}$ Cannon W. B. The James-Lange theory of emotion: a critical examination and an alternative theory. Amer. J. Psychol. 1927. Vol. 39, № 1-4.

4 Watson J. B. Behaviorism (Revised edition). Chicago: University of Chicago Press, 1930. 
спонукальною силою в психічному житті. У своїх пізніших працях він також говорив про афект (емоцію) як про «інтрапсихічні фактори, які дають поштовх фантазіям і бажанням». Психоаналітична література розрізняє (хоча й не використовує постійно) три аспекти афекту: енергетичний компонент інстинктивного потягу («заряд афекту»), процес розрядки, сприйняття остаточної розрядки (відчуття або почуття емоції). Розрядка і чуттєві компоненти розглядаються просто як вираження емоцій. Заряд афекту пов'язаний із кількісною або інтенсивнісною мірою афекту, а процеси розрядки сприймаються або відчуваються як якісні тони 5 .

Теорія 3. Фрейда та психоаналіз у цілому стосувалися негативних афектів. 3. Фрейд приділяв увагу захисним механізмам, але особливо виділяв механізм придушення. Коли придушення $\epsilon$ успішним, відбувається поділ передбачення й афективного компонента потягу. Інстинктивний потяг (або мотив) не може далі бути символом. Придушення може запобігати конфлікту або ж може формувати невротичний або психопатичний симптом. Якщо придушення не $\epsilon$ вдалим, то виникає конфлікт між несвідомими i підсвідомим системами. Оскільки такий афект негативний i пов'язаний із конфліктним уявленням, то він може обмежувати функції «Я» і сприяти психічним захворюванням.

У сучасній психологічній науці можуть розглядатися два великі класи когнітивних теорій: теорія «Я» і теорії, що розглядають розум як причину або компонент емоції. Центральним і широко поширеним поняттям у теорії «Я» $є$ «Я-концепція» - сприйняття індивідом самого себе і його усвідомлення свого «Я», що організовані в цілісний та інтегральний феномен, якому надається величезне пояснювальне значення.

У теорії «Я» стверджується, що чим більше сприйняття чи свідомість пов'язані з ядром особистості, тим більшою мірою вони включають почуття або емоції. Коли «Я-концепція» зазнає критики, індивід схильний до страху або до зайняття оборонної позиції. Коли ж «Я-концепція» підтверджується і схвалюється, то індивід відчуває інтерес або радість.

Теорії «Я» постійно підкреслюють важливість вивчення «почуттєвого змісту» (як протилежного строгому семантичному) для розуміння індивіда, зокрема переконують у важливості теоретичних напрацювань у роботі психотерапевтів. Дійсно, такий принцип використовується в декількох напрямах сучасної психотерапії (наприклад у групах психологічного тренінгу, групах знайомств, у гештальттерапії).

Деякі сучасні теорії розглядають емоцію як відповідь або як комплекс відповідей, зумовлених когнітивними процесами. Ці теорії

${ }^{5}$ Фрейд З. Психология бессознательного: сб. произведений. Москва, 1990. 156 с. 
мають спільну основу з поглядами на природу людини, які можуть бути простежені від Аристотеля, Хоми Аквінського, Дідро, Канта та інших філософів. Це ідеї про те, що: а) людина насамперед і найбільшою мірою - раціональна істота; б) раціональне за своєю сутністю $є$ добрим, а емоційне - поганим; в) когнітивні процеси повинні використовуватися як фактор, що контролює і заміщує емоції.

Одна 3 найбільш розроблених теорій емоцій і особистості цієї традиції- теорія Арнольд 6 . За Арнольд, емоція - результат послідовності подій, що описуються за допомогою понять сприйняття й оцінки. Розуміти що-небудь - це знати, чим є об'єкт, незважаючи на те, як він впливає на реципієнта. До виникнення емоції об'єкт повинен бути сприйнятий та оцінений. У відповідь на оцінку об'єкта, що так чи інакше впливає на реципієнта, виникає емоція як нераціональне прийняття або відкидання.

Відмінності між емоцією, сприйняттям й оцінкою визнаються, незважаючи на той факт, що оцінка сама по собі характеризується як пряма й інтуїтивна і чи не настільки ж безпосередня, як і сприйняття.

Арнольд установила відмінність між емоцією і мотивом. Емоція - це чуттєво-дієва тенденція, тоді як мотив - це дієвий імпульс плюс розум. Таким чином, мотивована дія $є$ функцією й емоцією когнітивних процесів.

Лазарус представив теоретичну конструкцію, в якій кожна емоція $\epsilon$ комплексною відповіддю, що складається 3 трьох компонентів ${ }^{7}$.

Перший компонент складається із сигнальних змінних або стимульних властивостей.

Другий - оцінює підсистема. Вона визначена як функція мозкових процесів, за допомогою яких індивід оцінює стимульну ситуацію.

Третій компонент системи емоційної відповіді включає три типи категорій відповіді: когнітивний, експресивний та інструментальний. Лазарус і його співробітники визначають перший із них (когнітивні реакції) як синонім того, що зазвичай описується як механізми захисту, такі як придушення, відмова, проекція. Вони найбільш повно досліджені в патології емоцій і поведінки.

Експресивні відповіді включають мімічні вирази, які розглядаються як поведінка, що не переслідує певної мети. Засоби вираження розділені на такі два типи, як біологічні та набуті.

Третій тип відповіді - інструментальна реакція - може ставитися до однієї 3 трьох категорій: символів, засобів і звичаїв. Вони $\epsilon$ цілеспрямованими. Функція символів - сигналізувати про наявність деякого афекту, коли немає інших форм комунікації. Символи можуть

6 Arnold M. B. Emotion, motivation, and the limbic system. Ann. N.Y. Acad. Sci. 1969. Vol. 159, № 3 .

${ }^{7}$ Lazarus R. S. Emotion as coping process. In: Arnold M. B. (ed.). The nature of emotion. Baltimore, 1968. 
також маскувати небажаний афект. Засоби - такі складні цілеспрямовані інструментальні дії, як агресія й уникнення. Звичаї такі культурно зумовлені засоби, як траур або способи залицяння.

Джеймс і Ланге висунули незалежно один від одного свою теорію. Джеймс стверджував, що «тілесні зміни слідують безпосередньо за сприйняттям факту, що хвилює. Наше переживання цих змін, залежно від того, як вони відбуваються, і $\epsilon$ емоцією» ${ }^{8}$. Тобто виникнення емоцій зумовлене зовнішніми впливами, змінами як у довільній руховій сфері, так і у сфері мимовільних актів серцевої діяльності, секреторної й судинної. Об'єкт впливає на орган почуттів і сприймається відповідним кірковим центром, як наслідок, виникає ідея цього об’єкта. Нервові імпульси, миттєво поширюючись відповідними каналами, змінюють стан м'язів, шкіри, судин. Ці зміни перетворюють об’єкт із того, що сприймається, в емоційно пережитий. Як стверджував Джеймс, «ми сумні, тому що плачемо, боїмося, бо тремтимо» ${ }^{9}$. Джеймс пов'язував емоції $з$ широким колом периферичних змін, Ланге ж - тільки із судинно-руховою системою (станом інервації і просвітом судин). Таким чином, периферія зміни, яка раніше розглядалася як наслідок емоцій, оголошувалася їх причиною ${ }^{10}$. Отут проблема довільної регуляції емоцій трактувалася спрощено: небажані емоції можна придушити, якщо навмисно чинити дії, характерні для позитивних емоцій.

Близькою до теорії Джеймса-Ланге $є$ теорія емоцій Р. Плутчика. Учений розглядав емоції як пристосувальні засоби, які відігравали важливу роль у виживанні індивідів на всіх еволюційних рівнях. Емоція (за Р. Плутчиком) - це комплексна відповідь, що відповідає одному 3 адаптивних біологічних процесів, загальних для всіх живих організмів $^{11}$. Він розглядає первинну емоцію як минущу, що запускається зовнішнім стимулом. С фізіологічні і поведінкові виразні комплекси діяльності, пов'язані 3 кожною емоцією і 3 кожною комбінацією емоцій (або вторинною емоцією). Комплекси для кожної 3 первинних емоцій на фізіологічному та поведінковому рівні визначаються як конструкти, справжня природа яких може бути виведена лише приблизно.

Р. Плутчик стверджує, що його теорія емоцій може бути використана при вивченні особистості в психотерапії. Він припустив, що особистісні риси можуть розглядатися як вторинні емоції, що репрезентують дві або декілька первинних. Р. Плутчик указував, що вісім первинних емоцій дають 28 парних комбінацій і 56 потрійних комбінацій, тобто всього

${ }^{8}$ James W., Lange K.G. Om Sindsbevaegelser. New York, 1885. P. 113.

${ }^{9}$ James W. The principles of psychology. N.Y., 1904. Vol. 2.

${ }^{10}$ James W., Lange K.G. Om Sindsbevaegelser. New York, 1885.

${ }^{11}$ Plutchik R. The evolutionary basis of emotional behavior. In: Arnold M. B, (ed.). The nature of emotion. Baltimore, 1968. 
84 різні емоції одного рівня інтенсивності. Припустивши існування хоча б чотирьох помітних рівнів інтенсивності, ми збільшимо цю кількість емоцій до 336. Р. Плутчик уважає, що розуміння способу змішування емоцій допомагає аналізу багатьох важливих емоційних феноменів. Наприклад, він пропонує такі формули: «гордість = гнів, радість»; «кохання = радість, прийняття»; «цікавість = здивування, прийняття»; «скромність = страх, прийняття»; «ненависть = гнів, подив»; «вина = страх, радість чи задоволення»; «сентиментальність = ухвалення, горе». Соціальні регулятори (феномени суперего) можуть бути зрозумілі в системі Плутчика як поєднання страху та інших емоцій, а тривожність - як поєднання страху й очікування.

Оригінальний внесок Дж. Сінгера в психологію афекту відображає його психоаналітичну підготовку й інтерес до когнітивних процесів, фантазії та уяви. Водночас подібність його когнітивно-афективного підходу з підходом І. Ізарда роблять його ідеї відповідними до теорії диференціальних емоцій. Дж. Сінгер, як й І. Ізарду і Далу, припустив, що емоції утворюють основну мотиваційну систему людського існування ${ }^{12,13}$. Його унікальний внесок заснований на клінічних та експериментальних дослідженнях, які підтверджують його основне припущення про те, що процеси фантазії та уяви пов'язують знання й афект, завдяки чому представляють основні людські мотиви.

За Дж. Сінгером, в основі взаємовідносин між афектом і знанням лежали спроби пристосування дитини до нового й змінного навколишнього середовища. Він припустив, як й І. Ізард, що новизна навколишнього середовища викликає інтерес, який сприяє пристосуванню. Успішне пристосування знижує збудження і викликає радість, тоді як велика кількість незасвоюваного матеріалу може викликати переляк, огиду або страх. Таким чином, афективні та когнітивні процеси проникають один в одного від початку життя.

Значущим результатом досліджень Сінгера було використання його уявлень про уяву й про афекти в практиці психотерапії (наприклад застосування поєднання уяви i дії (рольової гри), що допомагає пацієнтові досягти контролю над емоціями, думками і діями). Уява, здатність до фантазування можуть бути також засобом підвищення самоконтролю індивіда. Представлення як позитивних, так і негативних емоцій використовувалося Дж. Сінгером для придушення деяких емоційних станів. Наприклад, боязнь плавання долалася багаторазовим уявленням цієї дії хворим. Тривало-емоційне уявлення жінки використовувалося для нейтралізації гетеросексуального страху і гомосексуальних схильностей.

\footnotetext{
${ }^{12}$ Изард К. Е. Психология эмоций. СПб., 1999. 53 с.

${ }^{13}$ Имедадзе Н. В. К методу исследования уровня тревожности. Тбилиси, 1971. 154 с.
} 
I. Ізард уважає, що емоція складається 3 трьох взаємопов'язаних компонентів: 1) нейронної активності мозку і соматичної нервової системи; 2) діяльності поперечно-смугастої мускулатури або мімічної і пантомімічної експресії; 3) суб'єктивного переживання.

Усього (за І. Ізардом) є десять фундаментальних емоцій: 1) інтерес збудження; 2) задоволення - радість; 3) подив; 4) горе - страждання; 5) гнів - лють; 6) огида - огида; 7) презирство - зневага; 8) страх - жах; 9) сором - сором'язливість; 10) вина - каяття.

Ці емоції утворюють основну мотиваційну систему. Кожна фундаментальна емоція має унікальні мотиваційні й феноменологічні властивості. Фундаментальні емоції призводять до різних внутрішніх переживань i різних зовнішніх виражень цих переживань. Емоції взаємодіють між собою, тобто одна емоція може активувати, посилювати чи послаблювати іншу. Емоційні процеси взаємодіють із мотивами і з перспективними, когнітивними і моторними процесами та впливають на них.

Існують чотири основні типи мотивації (за І. Ізардом): 1) спонукання, 2) емоції; 3) афективно-когнітивна взаємодія (емоції поєднуються 3 думкою, уявленням), 4) афективно-когнітивна структура.

Розглянемо їх детальніше:

1) спонукання - голод, спрага, втома, біль, секс;

2) емоції - десять фундаментальних вищеперелічених емоцій;

3) афективно-когнітивні структури: інтроверсія - екстраверсія, скептицизм, егоїзм, рішучість, незворушність;

4) афективно-когнітивна взаємодія: емоція - емоція (горе - гнів і страх - сором - вина); емоція - спонукання (інтерес - секс; біль страх - сором - гнів); емоція - афективно-когнітивні структури (інтерес - інтроверсія; здивування - інтерес - задоволення - егоїзм).

Яскравим представником вітчизняної психології в розробленні теорії емоцій $€$ П.В. Симонов ${ }^{14}$. Він розробив інформаційну теорію емоцій. Учений визначив, що міра переживання емоції або міра емоційного стресу (Е) - функція двох чинників, а саме: а) значення мотивації або потреби (П) i б) різниці між інформацією, необхідною для іiі задоволення (Ін), та інформацією, доступною суб'єктові (Ід ). Це може бути виражене за допомогою формули: $\mathrm{E}=1$ (П / I, ...), де I = (Ін-Ід).

Відповідно до теорії емоції П.В. Симонова, виникнення емоції зумовлене дефіцитом прагматичної інформації (коли Ін більше, ніж Ід). Саме це викликає емоції негативного характеру: відразу, страх, гнів тощо. Такі позитивні емоції, як радість й інтерес, виникають у ситуації, коли отримана інформація збільшує ймовірність задоволення потреби в порівнянні з уже наявним прогнозом. Тобто коли Ід більше, ніж Ін.

${ }^{14}$ Симонов П. В. Что такое эмоция? Москва, 1966. 85 с. 
П.В. Симонов стверджує, що $є$ відносна незалежність нейронних механізмів потреби, емоції й прогнозу (або ймовірності досягнення мети) i що ця відносна незалежність механізмів передбачає різноманітність взаємодій між ними. Активація нейронного апарату емоції інтенсифікує потребу, а дефіцит або надлишок інформації схильні впливати на потребу за формулою: П = Е / (Ін-Ід). 3 іншого боку, зміна інтенсивності емоцій і потреб впливають на прогноз імовірності досягнення мети: Ін-Ід = Е / П.

Вітчизняний психолог С.Л. Рубінштейн указував на те, що людина переживає тільки те, що з нею відбувається і нею чиниться. Людина певним чином ставиться до того, що ііі оточує. Переживання цього ставлення людини до навколишнього світу становить сферу почуттів та емоцій. Почуття - це ставлення людини до світу, до того, що вона відчуває і робить, у формі безпосереднього переживання ${ }^{15}$.

Ознаки емоцій: 1) висловлюють стан суб'єкта і його ставлення до об'єкта; 2) відрізняються полярністю, тобто володіють позитивним чи негативним знаком (обидва полюси не обов'язково зовнішні, часто утворюється складна суперечність).

Вихідний момент, що визначає природу і функцію емоцій, полягає в тому, що, з одного боку, встановлюється зв'язок, взаємовідношення між перебігом подій, що відбуваються врозріз або відповідно до потреб індивіда, перебігом діяльності, спрямованої на задоволення цих потреб, а 3 іншого - 3 перебігом внутрішніх органічних процесів, що охоплюють основні вітальні функції, від яких залежить життя організму в цілому. Як наслідок, індивід налаштовується на відповідну дію або протидію.

С.Л. Рубінштейн виділяє три рівні емоційної сфери:

1) рівень органічної емоційно-афективної чутливості. Сюди належать елементарні так звані «фізичні» відчуття задоволення/незадоволення, пов'язані переважно 3 органічними потребами (забарвлення, тон окремого відчуття або вираз розлитого органічного самопочуття організму (безпредметна туга));

2) предметні почуття, відповідні предметні сприйняття і предметні дії. Тут більш високий рівень усвідомлення почуття. Усвідомлене переживання ставлення людини до світу. Можлива класифікація цих почуттів (інтелектуальні, естетичні, моральні);

3. Узагальнені почуття: почуття гумору, іронії, піднесеного, трагічного. Вони висловлюють загальні більш-менш стійкі світоглядні установки особистості.

Крім почуттів, С.Л. Рубінштейн описує афекти й пристрасті, які відрізняються від почуттів, але споріднені з ними.

${ }^{15}$ Рубинштейн С.П. Основы общей психологии. СПб., 1999. 207c. 
Афект (за С.Л. Рубінштейном) - це емоційний процес вибухового характеру, що протікає стрімко й бурхливо і який може дати розрядку в дії, що не підлягає свідомому вольовому контролю. Афективний стан виражається в загальмованості свідомої діяльності.

Пристрасті(за С.Л. Рубінштейном) - сильне, стійке й тривале почуття, яке, пустивши коріння в людині, захоплює його і володіє ним. Пристрасть завжди виражається в зосередженості, зібраності помислів і сил, їх спрямованості на єдину мету. У пристрасті яскраво виражений вольовий аспект прагнення, пристрасть є єдністю емоційних і вольових моментів, прагнення в якому переважають над думками.

Настрій - загальний емоційний стан особистості, що виражається в ладі всіх іiі проявів. Настрій не предметний, а особистісний (йому радісно!). Це розлитий загальний стан. Несвідомою є емоційна оцінка особистістю того, як на цей момент складаються для неї обставини (не знає причини).

За О.М. Леонтьєвим, емоційними називаються процеси внутрішньої регуляції діяльності. Вони відображають зміст, що мають об'єкти й ситуації, що впливають на суб'єкта, їх значення для здійснення його життя ${ }^{16}$.

До емоційних процесів належать афекти, власне емоції й почуття.

Афекти - сильні й порівняно короткочасні емоційні переживання, що супроводжуються яскраво вираженими руховими і вісцеральними проявами. Вони виникають у відповідь на ситуацію, яка вже фактично наступила, і в цьому сенсі $є$ нібито зрушеними до кінця події. Функція регулювання полягає в утворенні специфічного досвіду - афективних слідів, що визначають вибірковість подальшої поведінки стосовно ситуацій і їх елементів, які раніше викликали афект.

Власне емоції (за О.М. Леонтьєвим) - більш тривалі стани, які проявляються в зовнішній поведінці. Вони носять чітко виражений ситуаційний характер, тобто виражають оцінне особистісне ставлення до складних або можливих ситуацій, до своєї діяльності та своїх проявів у них. Вони також носять ідеаторний характер, тобто здатні передбачати ситуації й події, які реально ще не настали, і виникають у зв'язку з уявленнями про пережиті або уявні ситуації.

Почуття, за О.М. Леонтьєвим, носять предметний характер, що виникає в результаті специфічного узагальнення емоцій, що пов'язується 3 уявленням або ідеєю про деякий об'єкт. Розбіжність почуттів і емоцій - це розбіжність сталого емоційного ставлення до об’єкта та емоційної реакції на ситуацію, що минає.

Таким чином, огляд теоретичних напрямів у розвитку уявлень про емоції показав, що немає єдиної теорії, яка б відповідала на всі запитання

16 Леонтьев А.Н., Судаков К.В. Эмоции. Большая Советская Энциклопедия. Москва, 1978. Т. 30.347 с. 
психології емоцій. Тому слід розглядати ці теорії як взаємодоповнювальні, враховувати всі відкриті ними факти в теоретичній і практичній діяльності. Загальноприйнятим уважається те, що емоції (від лат. еmoveо - вражаю, хвилюю) - психічне відображення у формі безпосереднього упередженого переживання життєвого сенсу явищ і ситуацій, зумовленого ставленням їх об'єктивних властивостей до потреб суб'єкта. У процесі еволюції емоції виникли як засіб, що дозволяє живим істотам визначати біологічну значущість станів організму i зовнішніх впливів. Найпростіша форма емоцій - так званий «емоційний тон відчуттів» - безпосередні переживання, що супроводжують окремі важливі впливи (наприклад смакові чи температурні) i спонукають суб'єкта до їх збереження або усунення. Емоції за походженням $є$ формою видового досвіду (орієнтуючись на неї, індивід здійснює необхідні дії, доцільність яких залишається для нього прихованою). Емоції важливі й для отримання індивідуального досвіду. У цьому разі емоції викликають ситуації й сигнали, попередні прямі викликають емоції впливів, що дозволяє суб'єктові завчасно до них приготуватися. Рівень енергетичної мобілізації (активації) організму, необхідний для здійснюваних емоційних функцій, забезпечується вегетативною нервовою системою у взаємодії зі структурами головного мозку, складниками центрального нервового субстрата емоцій. Завдяки емоціям відбуваються зміни в діяльності органів дихання, травлення, серцевосудинної системи, залоз внутрішньої секреції, скелетної та гладкої мускулатури тощо. Емоції людини є продуктом суспільно-історичного розвитку. Вони належать до процесів внутрішньої регуляції поведінки. Будучи суб'єктивною формою вираження потреб, емоції передують діяльності щодо їх задоволення, спонукаючи і направляючи іiі.

Відсутність наслідування між теоріями, створеними в різні історичні епохи, не може не ускладнювати завдання ознайомлення 3 психологією емоцій, об'єднання в єдину узагальнену картину всього, що встановлено або стверджується в окремих концепціях і школах. Але хоча 3 різних сторін, на основі різної термінології і традицій ці концепції аналізують, проте одним і тим ж явищем дійсності є емоції; цього вже достатньо для того, щоб сформульовані в них положення за всієї зовнішньої несхожості іноді виявлялися більше взаємодоповнювальними, ніж суперечливими. Необхідно лише виробити звичку бачити крізь зовнішнє оформлення положень їх внутрішній зміст, відокремлювати його від випадкових супутніх деталей.

\section{2. Емоції та почуття особистості: порівняльний аналіз}

Емоції й почуття $є$ хоча i взаємозалежними, але самостійними психічними утвореннями афективної сфери людини. Головними проблемними аспектами цієї сфери є питання подібності й відмінності між емоціями й почуттями. Спільні риси: 
- $\epsilon$ переживаннями суб'єктивного ставлення до чого-небудь (когонебудь);

- сполучають ознаки процесу й стану;

- однаковий набір основних властивостей: спрямованість, тривалість і фазовість, знаковість і модальність, сила;

- загальні форми прояву (соматичні й психічні, зовнішні й внутрішні).

Відмінності:

- емоції є первинними, почуття - вторинними у філо- й онтогенезі;

- емоції - процеси короткочасні (секунди, хвилини), почуття довгострокові (години, дні, роки);

- емоції - порівняно прості моноявища, почуття - складні поліструктурні утворення;

- емоції безперервні у своєму протіканні й вираженні, почуття $\epsilon$ дискретними в часі (то проявляються, то загасають). Вони існують у двох формах (потенційній й актуальній). У потенційній формі відбувається відволікання від предмета почуття й воно ніяк не проявляється, в актуальній - протікання почуття є очевидним;

- емоції - переважно динамічний процесуальний складник афективного життя, почуття - переважно статичний складник, що характеризує стан суб'єкта;

- емоції є ситуативними, почуття - предметними. Емоції - це реакції на поточні події, обставини, що складаються неодмінно, фактори, що впливають у цей момент. Почуття ж під впливом ситуації відновлюються, спливають, із потенційної форми переходять в актуальну, але об'єкт, на який спрямовані почуття, залишається постійним;

- якщо в емоціях відбиваються відносини суб'єкта до будь-яких об'єктів дійсності, з якими він зіштовхується в реальності, то в почуттях відбиваються ставлення до найбільш значущих об'єктів (переважно до інших людей);

- для переживання почуття не $є$ обов'язковим безпосередній контакт з об'єктом, на який воно спрямоване. Емоції ж - результат безпосереднього діяння емоціогенного фактору;

- наслідком дискретності почуттів у часі й необов'язковості близькості стимулу $є$ непередбачуваність моментів їх поновлення, актуалізації;

- формування почуттів як у філо-, так і в онтогенезі визначається соціальними відносинами, а емоцій - взаємодією організму із середовищем. В емоціях відбиті біологічні фактори, а в почуттях соціальні;

- розходження у фізіологічних механізмах: в основі емоційних проявів лежать гомеостаз і рефлекторна робота мозку з акцентом на 
підкіркові утворення, фізіологічна основа почуттів - коркові процеси головного мозку.

Таким чином, почуття $є$ результатом узагальнення емоційного досвіду як в еволюції, так і в індивідуальному розвитку. Сформувавшись, почуття стають провідними утвореннями афективної сфери й починають визначати динаміку й зміст ситуативних емоцій. У цьому змісті почуття можна зіставити 3 провідними (за В.К. Вілюнасом) емоціями. Так, із любові до близької людини за різних обставин можуть виникати тривога за нього, сум або смуток при розлуці, радість при зустрічі, задоволення його успіхами й гнів при невдачах, щастя спілкування з ним або горе втрати тощо. Ці похідні ситуативні емоції уточнюють, конкретизують зміст почуттів у складних умовах, стимулюючи розвиток діяльності, викликаної цим почуттям.

Наведені відмінності дозволяють сформулювати визначення окремо для емоцій та окремо для почуттів 3 указівкою на їх загальні й специфічні ознаки.

Емоція - це короткочасне переживання суб'єктивного ставлення до об'єкта, що визначене потребово-мотиваційною установкою й актуалізоване безпосередньою взаємодією суб'єкта 3 цим об'єктом або його образом. Емоція виконує функцію безпосередньої регуляції в складних або можливих ситуаціях.

Можна дати й спрощене визначення емоції як короткочасного й безпосереднього переживання суб'єктивного ставлення до чогонебудь або кого-небудь у конкретних ситуаціях.

Почуття - це довгострокове й стійке переживання суб'єктивного ставлення до значущих об’єктів, що детермінується мотиваційною установкою переважно соціального характеру.

Зважаючи на те, що почуття в момент їх актуалізації переживають у формі емоцій, то функції, властиві емоціям, властиві й почуттям. На фізіологічному рівні - це мобілізаційна функція, на психологічному оцінна, на соціальному - сигнальна. Загалом, це функція безпосередньої регуляції. Специфіка полягає в тому, що регуляція на рівні почуттів здійснюється у сфері соціальних відносин, зокрема міжособистісних.

Таким чином, емоції й почуття повинні розглядатися як різні рівні афективних переживань подібно до того, як відчуття й сприйняття розглядаються як різні рівні перцепції:

1) в афективних явищах відбивається інтимне суб'єктивне ставлення людини до навколишнього світу й самого себе;

2) як у будь-якому психічному явищі в них включено два компоненти психічного (переживання й знання). Але переживання домінує i, як правило, добре усвідомлюється самим суб'єктом, тоді як пізнавальний складник залишається за межами усвідомлення; 
3) виникають афективні явища як результат безпосередньої взаємодії суб'єкта в навколишньому світі.

Переживання суб'єктивного ставлення до чого-небудь (кого-небудь) є родовою ознакою афективної сфери, що поєднує іії з вольовою в єдину сферу регуляторної функції психіки. Діалектичну пару цієї сфери психіки становить пізнавальна (перцептивна й інтелектуальна сфери). Видовими ознаками, що відрізняють афект (у широкому змісті слова) від волі, $\epsilon$ безпосередній характер цього переживання i його спрямованість. Вольові зусилля й дії опосередковані усвідомленими мотивами й цілями діяльності й спрямовані на самого суб'єкта (подолання себе). Емоційні переживання виникають і протікають стихійно, мимоволі, під впливом потреб і неусвідомлених мотивів, безпосередньо актуалізованих ситуацією або відповідними образами, і спрямовані на об'єкт, що викликав ці переживання (зокрема на самого себе). У цьому змісті афективною є сферою відбиття суб'єктнооб'єктних відносин, а вольова - суб'єктно-суб'єктних.

Уточнимо, що термін «афект» у цьому разі використовується не у вузькому значенні слова (як емоція, що надзвичайно інтенсивно протікає), а як позначення єдності в психіці людини емоцій і почуттів. Аналогічно до того, як використовується в науці термін «перцепція», зокрема як поняття, що поєднує сенсорні (відчуття) і перцептивні (сприйняття) процеси. Таке широке розуміння афекту має давню історичну традицію (Б. Спіноза, В. Вундт, Е. Клапаред) і продуктивно застосовується в сучасній науці (В.О. Ганзен).

Важливою особливістю афективних реакцій є тісне об'єднання в них динамічної й статичної сторін психічного. Перша персоніфікується психічними процесами, друга - станами. Недарма багато визначень емоцій і почуттів містять у собі поняття і процесу, і стану. Зумовлено це, певно, тим, що згадувалося домінування в них суб'єктивного компонента психічного - переживання. Дійсно, для самої людини акт переживання, незважаючи на його фазовість, з'являється як певний i досить однорідний за змістом шматок життя. Причому цей етап життя протікає в теперішньому часі. Своє ставлення до минулих або майбутніх подій і фактів ми однаково переживаємо в теперішньому часі, що тече, що суб'єктивно не розчленовується на окремі відрізки. Навіть тривале почуття суб'єктивно сприймається як щось цілісне на тлі різноманітних проявів життя людини: іноді вона «проносить» це почуття через усе своє життя. Саме ця перевага в суб'єктивному полі цілісності афективних явищ над їх фрагментарністю (як у просторовотимчасовому, так і в якісному аспекті) визначає злиття в них мінливого у вигляді процесів і стійкого у вигляді станів і навіть властивостей (коли говоримо про сталість почуттів, про сталість прояву своїх ставлень). 
Іншим фактором, що визначає злиття в афективній сфері понять процесу й стану, є її потребово-мотиваційна основа. Як відомо, потреба $\epsilon$ станом організму (особистості, групи), що створюється випробовуваним ним нестатком у чому-небудь, що виражає його залежність від цього. Потреба формує стан мотиваційної установки, тобто потенційну готовність до активної реакції в разі появи в полі сприйняття предмета, що відповідає цій потребі. Цей предмет $\epsilon$ мотивом діяльності. Так, потреба в їжі створює установку на ії пошук, а поява конкретного харчового об'єкта викликає реакцію на його досягнення. Поява цього конкретного об'єкта (як мотиву поведінки) відразу ж викликає в суб'єкта емоційне ставлення до нього. Саме це емоційне ставлення розкриває суб'єкту значущість цього об'єкта у вигляді позитивної або негативної оцінки й спонукає направляти на нього активність у вигляді бажань, потягів тощо. Це співвідношення мотивації й емоцій закріплене в твердженні про те, що емоція - це психічна форма існування потреб (С.Л. Рубінштейн).

Як стимул є зовнішнім побудником до пізнавальної діяльності, «запускає» механізм психіки через формування первинних образів, так i потреба $є$ внутрішнім побудником регуляторної діяльності, що включає механізм психіки через мотив (опредметнену потребу).

Наявність двох форм афективних явищ ніким не заперечується. Але водночас розведення емоцій $\mathrm{i}$ почуттів як різнорівневих явищ трапляється не так часто в навчальній психологічній літературі, ці два явища викладаються одночасно в загальному розділі, не виділяючись у самостійні параграфи. Найчастіше навіть їм дається загальне визначення ${ }^{17}$. Тому актуальною $є$ більш чітка вказівка на загальні й розпізнавальні особливості емоцій і почуттів.

Розгалуження, переплетення, злиття i, як наслідок, взаємодія емоцій створює базу для формування досить стійких структурованих психічних утворень, які ми називаємо почуттями. Природно, що не можна абсолютизувати ні протиставлення емоцій почуттям, ні їх єдність. Навряд можна виділити в людини моменти переживання «чистих» емоцій поза контекстом іï почуття або вказати на почуття, пережите не у формі емоцій. Недарма багато авторів визначають емоції як безпосереднє переживання почуттів. Проте спробуємо розвести ці поняття і явища, які вони відбивають.

Співвідношення емоцій i почуттів має непогану аналогію в співвідношенні відчуттів і сприйняттів. Однак компоненти перцептивної сфери розрізняються значно чіткіше, ніж компоненти афективної. Пов'язано це $з$ тим, що перцептивні процеси визначаються зовнішньою стимуляцією. Їх головне завдання - відбити у всій конкретності цю стимуляцію: подразники в цілісності - через образи

${ }^{17}$ Аверин В.А. Психология личности. СПб., 1999. 65 с. 
сприйняття, окремі властивості подразників - через сенсорні образи. Афективні ж процеси визначаються, як уже говорилося, внутрішніми потребово-мотиваційними факторами. Зовнішня стимуляція лише актуалізує ці фактори, відіграючи роль «пускової кнопки», що включає мотиваційні механізми. Ці внутрішні фактори є чимось цілим, що не розчленовується на окремі складники. Тому психічне відбиття в цій сфері нібито укрупнене й узагальнене, не має безлічі деталей, як у перцептивних образах.

Перцепція - це відбиття на рівні одиничного, афект - на рівні загального. Емоції й почуття - це узагальнена оцінка відносин індивіда до чого-небудь, за якої враховується істотне в об'єкті й опускається другорядне. Таким чином, афективні процеси значно гірше піддаються диференціюванню, ніж сенсорно-перцептивні. Проте емоції можна зіставити з відчуттями, а почуття - зі сприйняттями. Так, модальність відчуттів може розглядатися як аналог видів емоцій, показником, що узагальнює ïx, є знаковість. Це якісні (інформаційні) характеристики процесів. Така властивість відчуттів, як просторова локалізація, порівнюється зі спрямованістю емоцій. Це просторові характеристики. До категорії тимчасових характеристик належать тривалість і фазовість відчуттів i емоцій. Енергетичними параметрами $\epsilon$ інтенсивність відчуттів і сила емоцій. Як і сприйняття, почуття мають властивості предметності, цілісності, константності, структурності тощо.

\section{ВИСНОВКИ}

Аналіз теоретичних напрямів у розвитку уявлень про емоції показав:

1) немає єдиної теорії, яка б відповідала на всі питання психології емоцій. Тому слід розглядати ці теорії як взаємодоповнювальні, враховувати всі відкриті ними факти в теоретичній і практичній діяльності. Загальноприйнятим уважається факт, що емоції (від лат. emoveo - вражаю, хвилюю) - психічне відображення у формі безпосереднього упередженого переживання життєвого сенсу явищ i ситуацій, зумовленого ставленням їх об'єктивних властивостей до потреб суб'єкта;

2) порівняльний аналіз емоцій та почуттів показав, що психічні стани багатомірні, вони $є$ і системою організації психічних процесів у конкретний момент, і суб'єктивним ставленням суб'єкта до предмета чи явища, що відображається, й інтегральним психічним механізмом оцінки навколишньої дійсності;

3) емоція - це короткочасне переживання суб'єктивного ставлення до об'єкта, що визначене потребою i мотиваційною установкою й актуалізоване безпосередньою взаємодією суб'єкта 3 цим об'єктом або його образом. Емоція виконує функцію безпосередньої регуляції в складних або можливих ситуаціях. Можна дати й спрощене 
визначення: емоція - це короткочасне й безпосереднє переживання суб'єктивного ставлення до чого-небудь або кого-небудь у конкретних ситуаціях.

Почуття - це довгострокове й стійке переживання суб'єктивного ставлення до значущих об’єктів, що детермінується мотиваційною установкою переважно соціального характеру. Почуття завжди $\epsilon$ предметними;

4) взаємодія 3 навколишнім світом, реалізація потреб людини можуть відбуватися на різних рівнях активності та глибини афективного контакту із середовищем. Ці рівні (відповідно до складності поведінкового завдання, що стоїть перед суб'єктом) потребують різного ступеня диференціації афективного орієнтування та розроблення механізмів регуляції поведінки.

\section{АНОТАЦІЯ}

У роботі містяться концептуальні погляди на сутність емоційної сфери особистості, аналіз основних теорій, пов'язаних з емоціями та почуттями.

Підкреслюється, що емоційні стани є багаторівневим утворенням, у якому інтегровані психічні прояви суб'єкта в конкретний момент і де відображається його ставлення до ситуації життєдіяльності. Огляд теоретичних напрямів у розвитку уявлень про емоції показав, що немає єдиної теорії, яка б відповідала на всі питання психології емоцій.

Установлено, що емоції й почуття розглядаються як самостійні психічні утворення афективної сфери людини, хоч і взаємозалежні. Поряд зі спільними рисами (переживання суб'єктивного ставлення до світу, поєднання ознак процесів і станів, однаковість набору основних властивостей (спрямованості, тривалості й фазовості, знаковості й модальності, сили; спільності форм прояву (соматичні й психічні, зовнішні й внутрішні)), між емоціями та почуттями є значні відмінності (емоції є первинними, а почуття - вторинними у філо- й онтогенезі; емоції - процеси короткочасні, а почуття - довгострокові; емоції порівняно прості моноявища, почуття - складні поліструктурні утворення; емоції - переважно динамічний процесуальний складник афективного життя, почуття - переважно статичний складник, що характеризує стан суб'єкта; емоції $\epsilon$ ситуативними, почуття предметними тощо).

\section{ЛІТЕРАТУРА}

1. Аверин В.А. Психология личности. Санкт-Петербург, 1999. 65 с.

2. Дарвин Ч. Сочинения. Том 5. Происхождение человека и половой отбор. Выражение эмоций у человека и животных. Москва, 1953. $215 \mathrm{c}$.

3. Изард К.Е. Психология эмоций. Санкт-Петербург, 1999. 53 с. 
4. Имедадзе Н.В. К методу исследования уровня тревожности. Тбилиси, $1971.154 \mathrm{c.}$

5. Леонтьев А.Н., Судаков К.В. Эмоции. Большая Советская Энциклопедия. Москва, 1978. Т. 30. 347 с.

6. Павлов И.П. Полное собрание сочинений. 2-е изд. / за ред. Э. Ш. Айрапетьянц. Ленинград, 1951. Т. 1. 324 с.

7. Рубинштейн С.П. Основы общей психологии. Санкт-Петербург, 1999. $207 \mathrm{c}$.

8. Симонов П.В. Что такое эмоция? Москва, 1966. 85 с.

9. Фрейд 3. Психология бессознательного : сб. произведений. Москва, 1990. 156 с.

10. Arnold M.B. Emotion, motivation, and the limbic system. Ann. N.Y. Acad. Sci. 1969. Vol. 159, № 3. DOI: 10.1111/j.1749-6632.1969.tb12996.x

11. Cannon W.B. The James-Lange theory of emotion: a critical examination and an alternative theory. Amer. J. Psychol. 1927. Vol. 39, № 1-4.

12. James W. The principles of psychology. N.Y., 1904. Vol. 2.

13. James W., Lange K.G. Om Sindsbevaegelser. New York, 1885. P. 79-103.

14. Lazarus R. S. Emotion as coping process. In: Arnold M. B. (ed.). The nature of emotion. Baltimore, 1968.

15. Plutchik R. The evolutionary basis of emotional behavior. In: Arnold M. B. (ed.). The nature of emotion. Baltimore, 1968.

16. Watson J. B. Behaviorism (Revised edition). Chicago: University of Chicago Press, 1930.

\section{Information about the author: Mykhaylyshyn U. B.,} D.Sc. in Psychology, Full Professor, Head of the Department of Psychology

Uzhhorod National University 14, Universytetska str., Uzhgorod, 88000, Ukraine 